\title{
Large Extra-Articular Lipoma of the Knee: An Unusual Case Report
}

Omar Mourafiq $^{1 *}$, Mohamed Tbouda ${ }^{2}$, Hicham Benomar ${ }^{1}$, Abdrahim Zaizi ${ }^{1}$, Jalal Elmekkaoui ${ }^{1}$, Bouchaib chefry ${ }^{1}$, Jalal Boukhriss $^{1}$, Driss Bencheba ${ }^{1}$, Mostapha Boussouga ${ }^{1}$

${ }^{1}$ Department of Orthopaedic Surgery and Traumatology II, Mohamed V Military Hospital, Faculty of Medicine and pharmacy of Rabat, Mohamed V University, Rabat 10000, Morocco

${ }^{2}$ Department of Histopathology, Mohamed V Military Hospital, Rabat 10000, Morocco

DOI: $\underline{10.36347 / \text { sjmcr.2020.v08i06.001 }}$

| Received: 17.05.2020 | Accepted: 26.05.2020 | Published: 06.06.2020

*Corresponding author: Omar Mourafiq

Abstract

Introduction: Solitary lipoma is the most common soft tissue tumor. It is a benign proliferation of mature adipocytes. The functional squatting and social discomfort motivates surgical removal after eliminating the malignant degeneration. Case Report: We report the case of a 64-year-old diabetic, hypertensive patient under treatment who was referred to us for the management of a pre-patellar lipoma measuring $96 \times 53 \times 80 \mathrm{~mm}$. Physical examination showed a massive tumor with a lipomatous consistency. Nuclear magnetic resonance imaging (MRI) shows no signs of malignancy. Intraoperatively, removal of the tumor was without difficulty with a cleavage plane between the skin and the tumor. Now the patient is relieved of the overweight on his knee and can perform his squatting movements. Conclusion: Although benign in nature, large lipoma is often a source of significant functional discomfort. Its treatment is surgical. The surgeon's obsession remains the malignant degeneration whose risk is proportional to the size of the lipoma.

Keywords: Lipoma; knee; complete excision.

Copyright @ 2020: This is an open-access article distributed under the terms of the Creative Commons Attribution license which permits unrestricted use, distribution, and reproduction in any medium for non-commercial use (NonCommercial, or CC-BY-NC) provided the original author and source are credited.

\section{INTRODUCTION}

Lipoma is the most frequent tumor of all benign soft tissue tumors (16 to $50 \%$ depending on the studies) [1-3]. It is much more frequent than liposarcoma. Its pathogenesis is poorly understood, but it is usually considered to be a true mesenchymal tumor whose development is independent of metabolism and diet. Often unique ( 80 to $95 \%$ of cases), the typical lipoma is a homogeneous and circumscribed fat mass [4].

\section{Case Report}

This is a 64-year-old patient, with a history of diabetes and hypertension under treatment, who for 18 years has had a mass on the anterior surface of the right knee that was painless and gradually increasing in volume (Figure 1). An ultrasound of the right knee was performed and returned in favor of impure fluid or tissue formation in the anterior part of the knee. An MRI of the right knee was performed and shows a well limited, oval, subcutaneous anterior knee formation with regular contours, in hyper signal, not rising after gado injection, measuring $96 \times 53 \times 80 \mathrm{~mm}$, which is in favor of a lipomatous knee formation (Figure 2).

The surgery was performed under spinal anesthesia. A large soft encapsulated mass of the knee was located subcutaneously and in front of the patellar tendon. Complete excision was performed successfully with rigorous hemostasis. The resected mass was a polylobular fatty mass, measuring $9 \times 5 \times 8 \mathrm{~cm}$ in size, and then skin closure (Figure 3).

Histological examination confirmed the diagnosis of lipoma and excluded malignancy (Figures $4,5)$. The postoperative course was uneventful, and the patient left the hospital on the third postoperative day. 


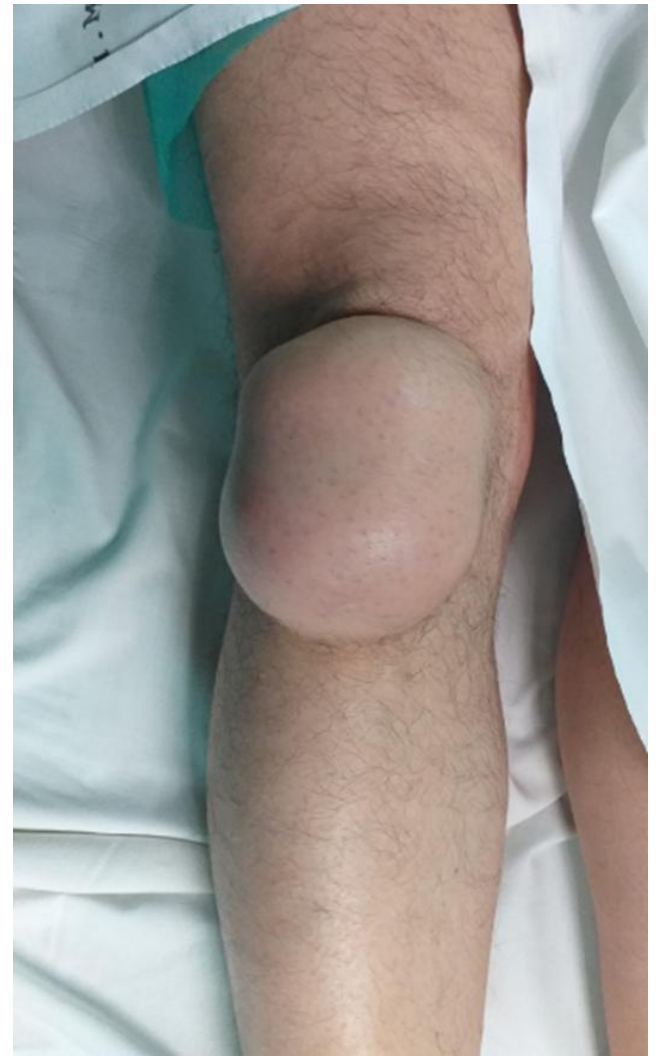

Fig-1: Voluminous mass of the anterior surface of the right knee

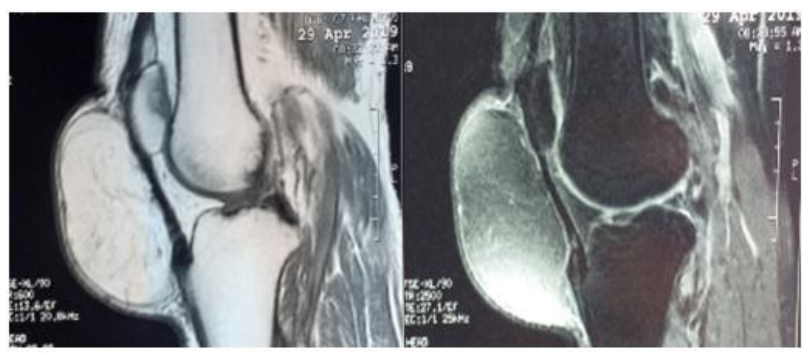

Fig-2: MRI appearance in favor of subcutaneous lipomatous formation of the anterior aspect of the knee

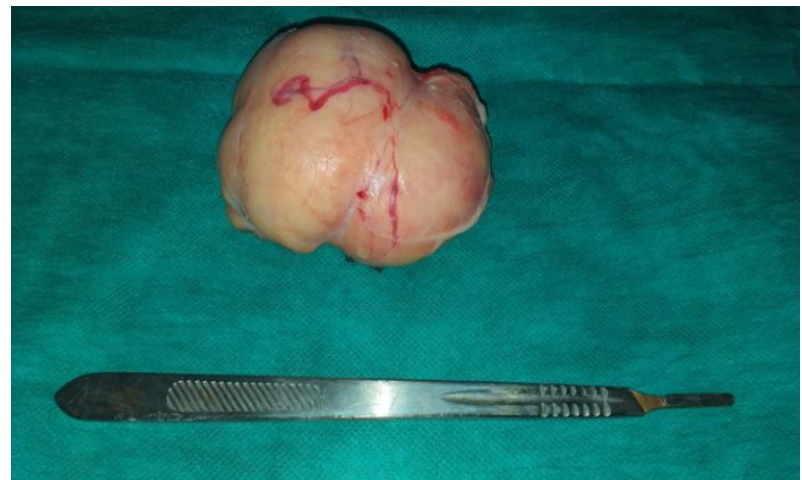

Fig-3: Tumor after resection was an encapsulated fatty mass, measuring $9 \times 5 \times 8 \mathrm{~cm}$ in size

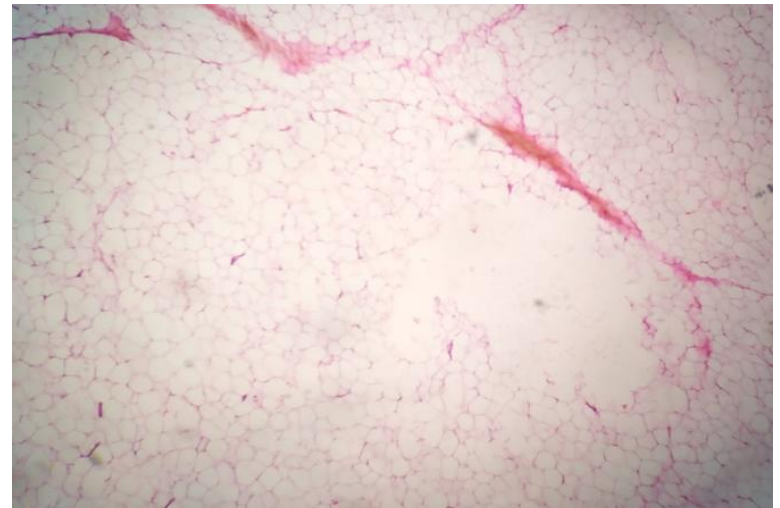

Fig-4: Microscope image showing tumor proliferation made of adipose lobules (HE x 100)

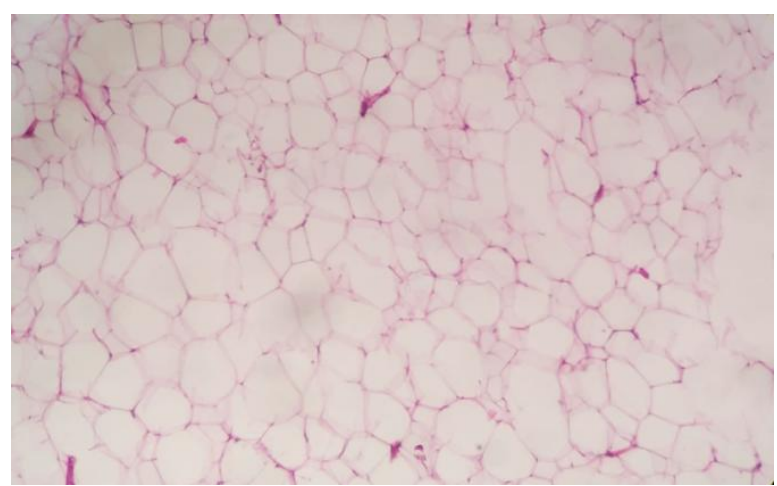

Fig-5: Microscope image showing adipocytes which are regular without atypia and mitosis (HE $x$ 200)

\section{DiscuSSION}

Giant lipomas affect women more often than men and occur between the fourth and fifth decade of life. The complaint is essentially aesthetic since they are massive and unsightly in appearance. But the functional discomfort is far from negligible. They can arise from either deep or superficial structures and be single or multiple (lipomatosis) [6] Lipomas are commonplace soft-tissue tumors, and can be found anywhere in the body [7]. Lipomas have a predilection for the trunk and are the most uncommon tumors of the knee [8]. An increased incidence of lipomas is associated with obesity, diabetes mellitus, elevation of serum cholesterol, radiation, familial tendency, chromosomal abnormalities [9]. MRI scanning is essential in the search for signs of malignant degeneration [5]. The Lipoma manifests as a high intense signal in T1-w and $\mathrm{T} 2-\mathrm{w}$ sequences, which is analogous to the signal intensity of the subcutaneous fatty tissue [10]. When treatment of lipoma is warranted, complete surgical excision is advised and it is easily performed because the capsule that surrounds the tumor presents a clear cleavage plane [11]. Macroscopically, lipomas are soft, yellow or tan coloured mobile structures which are generally well defined from surrounding tissues. Histologically, they are composed of well-defined adipose tissue with à fibrous capsule [12]. Malignant change of lipoma to liposarcoma is virtually unknown and should be considered [13]. 


\section{CONCLUSiON}

Large extra-articular lipoma of the knee is a very rare entity, and many cases might be ignored due to their silent nature. Although benign in nature, large lipomas are often a source of significant functional discomfort. Its treatment is surgical. The surgeon's obsession remains malignant degeneration.

\section{REFERENCES}

1. Lattes R. Tumors of the soft Tissues. Atlas of tumor pathology second series. Armed Forces Institute of pathology edit., Washington D.C. 1981; 1:53-150

2. Enziger FM, Weiss SW. Liposarcoma Soft Tissue tumors. Mosby - Year Book edit. St Louis. 1995: 431-66.

3. Marques MC, Garcia H. Lipomatous Tumors In: De Schepper AM. Imaging of soft Tissue Tumors. Springer edits, Berlin. 1997: 191-207

4. Fuchs A, Henrot P, Walter F, Lochum S, Vignaud JM, Stines J, Blum A. Tumeurs graisseuses des parties molles des membres et des ceintures de l'adulte. J radiol. 2002 Sep;83(9 Pt 1):1035-57.

5. Dabloun S, Khechimi M, Jenzeri A, Maalla R. Lipome géant du dos: à propos d'un cas. InAnnales de Dermatologie et de Vénéréologie 2015 Jun 1 (Vol. 142, No. 6-7, p. S353). Elsevier Masson.

6. Ramos-Pascua LR, Guerra-Álvarez OA, SánchezHerráez S, Izquierdo-García FM, MaderueloFernandez JA. Intramuscular lipomas: Large and deep benign lumps not to be underestimated. Review of a series of 51 cases. Revista Española de Cirugía Ortopédica y Traumatología (English Edition). 2013 Nov 1;57(6):391-7.

7. Marui T, Yamamoto $\mathrm{T}$, Kimura $\mathrm{T}$, Akisue $\mathrm{T}$, Nagira K, Nakatani T, Hitora T, Kurosaka M. A true intra-articular lipoma of the knee in a girl. Arthroscopy: The Journal of Arthroscopic \& Related Surgery. 2002 May 1;18(5):1-4.

8. Dalla Rosa Nogales J, Nogales Zafra JJ. Bilateral Simultaneous Tibial Tubercle Avulsion in an Adolescent Football Player with Previous Bilateral Osgood-Schlatter Disease. Case reports in orthopedics. 2019;2019.

9. SW Weiss JR. Goldblum. "Soft tissue tumors".(5th ed) St Louis, MO: Mosby. 2007

10. Bankaoglu M, Ugurlar OY, Ugurlar M, Sonmez MM, Eren OT. Intra-articular lipoma of the knee joint located in the posterior compartment: A rare location. Northern clinics of Istanbul. 2017;4(1):89.

11. Ilhan H, Tokar B, Išiksoy S, Koku N, Pasaoglu Ö. Giant mesenteric lipoma. Journal of pediatric surgery. 1999 Apr 1;34(4):639-40.

12. Rahmani G, McCarthy P, Bergin D. The diagnostic accuracy of ultrasonography for soft tissue lipomas: a systematic review. Acta Radiol Open. 2017;6(6): 2058460117716704

13. Jones AP, Lewis CJ, Dildey P, Hide G, Ragbir M. Lipoma or liposarcoma? A cautionary case report. J Plast Reconstr Aesthet Surg. 2012 Jan;65(1):e11-4. 